\section{Presence of cadmium residues in muscle, liver and kidney of Bubalus bubalis and histological evidence}

\author{
Roberta Barrasso, ${ }^{1}$ Edmondo Ceci, ${ }^{1}$ \\ Laura Stinga, ${ }^{2}$ Giuseppina Tantillo, ${ }^{1}$ \\ Giancarlo Bozzo ${ }^{1}$ \\ ${ }^{1}$ Department of Veterinary Medicine, \\ University of Bari "Aldo Moro"; \\ ${ }^{2}$ Specialization degree in Food \\ Inspection of Animal Origin, Veterinary \\ Medicine, University of Bari "Aldo \\ Moro", Bari, Italy
}

\section{Abstract}

Cadmium (Cd) concentrations were evaluated in the samples of kidney, liver and muscle of sixty-six buffaloes regularly slaughtered. Forty were raised in Campania, in the territory between the province of Naples and Caserta and twenty-six were bred in Apulia, in the province of Bari. Two aliquots were prepared for the renal and hepatic samples: one intended for the chemical analysis and the other one intended for histological investigations. Muscle samples were the subject of purely chemical investigation. In the group of forty animals raised in the Campania region, the limits imposed by EC Reg. 1881/2006 and EC Reg. $488 / 2014$ were exceeded in three renal samples, which showed values of $1.53,1.22$ and $1.1 \mathrm{mg} / \mathrm{kg}$ respectively; in three hepatic samples, which presented values of 0.72 , 0.64 and $0.61 \mathrm{mg} / \mathrm{kg}$, and in five muscle samples, with values of $0.16,0.16,0.09$, 0.08 and 0.07 , respectively. On the other hand, in the group of animals raised and slaughtered in the province of Bari, none of the twenty-six samples examined exceeded the limits imposed by the European regulations. The histological analysis showed typical, but not pathognomonic lesions in the renal samples from the animals raised in the provinces of Naples and Caserta. The levels of $\mathrm{Cd}$ contamination found in the samples examined suggest that it would be correct to exclude from the human consumption, as it happens for the equines, the kidney and the liver, especially from the animals raised in some geographical areas with a high rate of pollution.

\section{Introduction}

Elements can be classified as "essential" and "non-essential" following their functions in biota. Non-essential elements are very resistant to natural degradation and keep their toxicity unchanged for a long time; for this reason, their environmental concentration should be monitored and maintained at very low levels (Lara et al., 2012; Paßlack et al., 2014; Binkowski et al., 2016)

There is a broad range of toxic effects caused by metals, including carcinogenicity, impaired reproduction, teratogenicity, immunosuppression, cardiovascular and pulmonary diseases, nephrotoxicity and neurotoxicity (Roychoudhury et al., 2010). Aiming to protect human health and ensure the quality of food, an important component of any food safety programme is the control and monitoring of residues and contaminants in living organisms (EFSA, 2004a).

Environmental pollution, the main sources of which constitute increasing industrial production, transportation and plant protection chemicals used in agriculture, results in serious health hazards to humans as well as animals (Demirel et al., 2008). Among the farm animals, horses are the species that most easily accumulates the metal in kidney, liver and muscle, but also cattle, sheep and goats can contain high concentrations of $\mathrm{Cd}$, if fed with highly contaminated feed (Groten et al., 1994; Plumlee et al., 1996; Giofrè et al., 2000).

The compounds of some non-essential elements, most cadmium compounds, are relatively easily soluble in water, have high mobility and tend to accumulate in living organisms (Nagajyothi et al., 2008). Cd concentrations in the food chain are of current interest for risk assessment. The Scientific Report of EFSA (2012) regarding the cadmium dietary exposure in the European population, has indicated that the ingestion of liver and kidneys of horses, ruminants and wildlife can considerably contribute to human overall $\mathrm{Cd}$ exposure. According to the World Health Organization (WHO) and the United Nations Food and Agriculture Organization (FAO) in 2003, the amount of Cd that can be ingested weekly by an adult man is 500 $\mu \mathrm{g}$, i.e. $7 \mu \mathrm{g} / \mathrm{kg}$ of weight body corresponding to $1 \mu \mathrm{g} / \mathrm{kg}$ per day and a dose of 100 $\mu \mathrm{g} / \mathrm{dL}$ is considered fatal. The maximum admissible limit in drinking water is $3 \mu \mathrm{g} / \mathrm{L}$; in foods the average concentration should not exceed $0.04-0.05 \mathrm{mg} / \mathrm{kg}$ (D.M. of 12/29/2003). The International Agency for Research on Cancer (IARC) and the US National Toxicology Program have classified the $\mathrm{Cd}$ as a "category 1 carcinogen".

$\mathrm{Cd}$ contamination is of particular importance when it derives from plant products, as they represent the raw material for the production of feed for zootechnical pur-
Correspondence: Roberta Barrasso, Department of Veterinary Medicine, University of Bari "Aldo Moro"

Strada Provinciale per Casamassima km 3, 70010 Valenzano (BA), Italy.

Tel: +39.080.5443851 - Fax: +39.080.5443855

E-mail: roberta.barrasso@uniba.it

Key words: Cadmium, Bubalus bubalis, Muscle, Liver, Kidney.

Acknowledgments: The authors thank Stefano Sportelli for providing invaluable technical assistance in the laboratory.

Contributions: RB, EC, GB and GT designed the experiment; GB, EC and LS performed the experimental procedures; RB conducted the statistical analysis. All authors contributed equally writing the paper.

Conflict of interest: the authors declare no potential conflict of interest.

Funding: none

Received for publication: 10 July 2018 .

Revision received: 27 September 2018.

Accepted for publication: 12 October 2018.

This work is licensed under a Creative Commons Attribution-NonCommercial 4.0 International License (CC BY-NC 4.0).

CCopyright R. Barrasso et al., 2018 Licensee PAGEPress, Italy

Italian Journal of Food Safety 2018; 7:7684

doi:10.4081/ijfs.2018.7684

poses. The latter, destined for livestock animals, are therefore the weak link in the entire production chain (Mantovani et al., 2002). Cd levels in air, water and soils have been increasing during recent years, particularly because of human activity. It is widely introduced into the food chain and normally found in variable concentrations in foods of plant or animal origin (Antoniou et al., 1989).

The most serious problem about cadmium is that this metal is characterized by a remarkable capacity for penetration into the cell, by a high bio-persistence and by a particular difficulty of elimination (Nordberg et al., 1994). Winds, as well as rainwater, play a fundamental role in the spread of metal even in areas very far from the main pollution sites. The $\mathrm{Cd}$ of the atmosphere contributes about $23 \%$ to the pollution of the water as it is transported by atmospheric currents even at great distances from the most urbanized centres (Mantovani et al., 2002). The accumulation of $\mathrm{Cd}$ in the soil is continuous and systematic, so that even the vegetables, through the root system, absorb 
it in a constant way, involving the contamination of the herbivores (Mantovani et al., 2002).

The elective deposit sites, in all animal species, are represented by the cortical portion of the kidney, especially in the first part of the proximal contorted tubule, and by the liver. Renal injury induced by $\mathrm{Cd}$ is characterized first of all by proximal tubular dysfunction, which is believed to be irreversible at advanced stages (Mitsumori et al., 1998). Other typical effects of Cd exposure are: (i) disturbances of calcium metabolism, (ii) hypercalciuria and (iii) formation of stones in the kidney. Finally, high exposure can lead to lung and prostate cancer.

In the kidneys and liver can be found values equal to $50-60 \%$ of all the $\mathrm{Cd}$ present in the organism. To a lesser extent, the metal is deposited at the level of the muscle masses and in smaller quantities in the pancreas, testes, spleen, breast tissue, ovaries, uterus, vascular walls and arterioles (Pozzali et al., 1995).

In general, the level of contamination of organs and muscle tissue is directly proportional to the geographical area in which these animals are bred and to their age (Alnaemi HS, 2011). The Buffalo breeding represented a new reality. Until recently the buffalo farming, bred mainly in Campania, in the lower Lazio, Apulia and Calabria, was finalized almost exclusively to the use of milk and its derivatives and the production of the buffalo meat was totally rejected. Today, it is believed that even the males, about $50 \%$ of the births, represent an important economic resource thanks to the dietetic-nutritional and organoleptic characteristics of its meat and the wide commercial possibilities of this product (Mehmood et al., 2014). The buffalo meat is a food suitable for the needs of modern life, characterized by its typical bright red colour for its contents in stearic and linoleic acids, also has a cholesterol content significantly lower than that of beef meat. It lends itself well to the various meat preparations, it is more tender than the beef meat also because generally these animals are mostly bred in the wild, free to graze (Mehmood et al., 2014). This aspect implies that if the breeding area and/or the feed used are very contaminated, they affect the meat. To date, this species is not yet included in the EC Regulation $1881 / 2006$, nor in the most recent EC Regulation 488/2014. Also the National Residual Plan (NRP) assimilates, with a note from the Ministry of Health No. 0021474-P-01/12/2009, the buffalo species to the bovine ones.

According to the EC Regulation $1881 / 2006$ latest amended by EC
Regulation 488/2014, the maximum level for $\mathrm{Cd}$ in liver and kidney of bovine animals, sheep, pig, poultry and horse is 0.50 $\mathrm{mg} / \mathrm{kg}$ and $1.0 \mathrm{mg} / \mathrm{kg}$ fresh weight respectively; while in meat (excluding offal) of bovine animals, sheep, pig and poultry is $0.050 \mathrm{mg} / \mathrm{kg}$ fresh weight.

In order to acquire data on the Cd concentrations in the buffalo species (Bubalus bubalis), a less investigated specie of zootechnical interest and mistakenly assimilated to the bovine, the aim of the present study was to provide preliminary indications about the incidence of this nonessential element in samples of liver, kidney and muscle (longissimus dorsi) of Bubalus bubalis. We compared Cadmium concentration in different farms in Apulia and Campania regions, considered at risk of environmental contamination and we tried to assess a correlation between $\mathrm{Cd}$ levels in tissues and organs and the presence of histological lesions.

\section{Materials and Methods}

\section{Sampling}

The study was conducted in the period between March and May 2018 on a total of sixty-six buffaloes regularly slaughtered, aged between 4 and 82 months and bred in free paddocks outdoors. Forty were raised in Campania, in the territory between the province of Naples and Caserta and twentysix were bred in Apulia, in the province of Bari. The animals were divided into three experimental groups, according to their different age: a group under 6 months of age (group A), a group aged between 7 months and 3 years (group B) and a group of animals aged more than 3 years (group C).

After post-mortem examination, performed by the Official Veterinarian and before the entry of the carcasses in the precooling and cooling tunnel, samples of kidney, liver and muscle (longissimus dorsi) were collected. Then the samples were transported, under refrigeration, to the laboratories of the Food Safety Section of the Department of Veterinary Medicine at Bari University, where two aliquots were prepared for the renal and hepatic samples: one intended for the chemical analysis (stored frozen) and the other one intended for histological investigations (fixed in $4 \%$ buffered formalin). Muscle samples were the subject of purely chemical investigation.

\section{Samples for chemical testing: atomic absorption spectrometry}

For the qualitative and quantitative detection of cadmium, all the samples were subjected to digestion at $120^{\circ} \mathrm{C}$ for 240 minutes in a DK6 Heating Digester (VELP Scientifica). For each animal, aliquots of $2,5 \mathrm{~g}$ of muscle and $0,5 \mathrm{~g}$ of liver and kidney were placed into a $25 \mathrm{~mL}$ glass digestion vessel and $8 \mathrm{~mL}$ of concentrated nitric acid $\left(\mathrm{HNO}_{3}\right)$ and $3 \mathrm{~mL}$ of hydrogen peroxide $\left(\mathrm{HClO}_{4}\right)$ were added to the vessel.

After cooling, the final volume of the solution was made up to $25 \mathrm{~mL}$ with distilled water. High-quality water, obtained using a Milli-Q system (Millipore), was used exclusively. Cd standard solutions $\left(1000 \mathrm{mg} / \mathrm{mL}^{-1}\right)$ were obtained from Panreac (Spain) and diluted as necessary to obtain working standards. Concentrated nitric acid (65\% w/v Merck), hydrogen peroxide $(30 \% \mathrm{w} / \mathrm{v}$ Fluka), and ammonium dihydrogenphosphate (Fluka) were also used. A Solar M Series-Unicam (Cambridge UK) 939QZ atomic absorption spectrometer equipped with a GF90 electrothermal atomizer (ET-AAS). Pyro lytic platforms were obtained from ATI-Unicam. This instrument is equipped with both a deuterium-arc background corrector and a Zeeman correction device, which facilitates comparison between both correction modes. Argon was used as the inert gas. Background-corrected integrated absorbance was used in all cases as the analytical signal. Each sample was subjected, in a graphite furnace, to the thermal cycle divided into: drying, pyrolysis, atomization and final cleaning. Measurements were performed at $228.8 \mathrm{~nm}$ for $\mathrm{Cd}$ and hollow cathode lamps were operated at $7 \mathrm{~mA}$. The graphite furnace temperature program for the determination of Cd in meat samples by ET-AAS using the digestion technique was as follows: (i) Drying 1: ${ }^{\circ} \mathrm{C}$; ramp $/{ }^{\circ} \mathrm{C} \mathrm{s}-1135$; hold $/ \mathrm{s}$ : 70; 10; 20. (ii) Drying $2:{ }^{\circ} \mathrm{C}$; $\operatorname{ramp} /{ }^{\circ} \mathrm{C} \mathrm{s}-1136$; hold/s: 100; 5; 60. (iii) Pyrolysis: ${ }^{\circ} \mathrm{C}$; $\mathrm{ramp} /{ }^{\circ} \mathrm{C} \mathrm{s}-1137$; hold $/ \mathrm{s}: 900 ; 100 ; 35$. (iv) Atomization: ${ }^{\circ} \mathrm{C}$; $\operatorname{ramp} /{ }^{\circ} \mathrm{C} \mathrm{s}-1138$; hold $/ \mathrm{s}$ : 2000; Full Power; 4. (v) Cleaning: ${ }^{\circ} \mathrm{C}$; $\mathrm{ramp} /{ }^{\circ} \mathrm{C} \mathrm{s}-1139 ;$ hold/s: 2400; 1000; 4.

Purge gas (argon) flow rate: $2 \mathrm{~L} \mathrm{~min}^{-1}$ 140 in all steps, except in atomization, when the gas flow was interrupted. To decrease the risk of $\mathrm{Cd}$ contamination, the use of glassware was reduced to a minimum and plastic (polypropylene) vessels of the type commonly used to collect clinical samples were used to prepare and store the solutions or suspensions. Pipette tips were also of polypropylene. All the glassware and plastic ware was nitric acid-washed and rinsed with ultrapure water. An external calibration curve was constructed to determine Cd. The working standards were prepared by serial dilution of stock solutions with the addition of 0.014 mole/ $/ \mathrm{L}^{-1} 148$ nitric acid. The limit of detection (LOD) is expressed 
as three times the standard deviation (SD) of the mean result using a large number of blanks $(n \geq 20)$. The limit of quantification (LOQ) is expressed as two times the LOD (6 SD). The limits of quantification (LOQ) for the element were estimated as 0.005 $\mathrm{mg} / \mathrm{kg}^{-1} \mathrm{Cd} 152$ dry weight. The precision (i.e. internal reproducibility; measured as residual standard deviation RSDr in \%) was calculated to be $6-10 \%$ for $\mathrm{Cd}$ in the present study $(n=30)$. The analytical procedure was validated using certified reference material (BCR 668). Each sample was analysed in duplicate and the error did not exceed $7 \%$.

\section{Statistical analysis}

A statistical descriptive analysis based on central tendency and concentration indexes was carried out for the two groups of animals according to their geographical origin, each one divided in three subgroups of different age. We realized box plots in which the trends of the $\mathrm{Cd}$ concentration in the three organs involved in the study (kidney, liver and muscle) were highlighted to provide a framework of the changes in its amount according to the geographical provenience, the age and the samples. The results were expressed as average, median, Standard Error (SE), Standard Deviation (SD), kurtosis, skewness, minimum and maximum. Then, we carried out the parametric analysis ( $\mathrm{r}$ Pearson correlation) of the $\mathrm{Cd}$ concentrations in the various tissues to verify a possible correlation among the three samples studied.

\section{Samples for histological testing}

The samples of kidney and liver collected for histological examination were processed as follows: (i) fixed in 10\% neutral buffered formalin for 48 hours; (ii) embedded in paraffin wax; (iii) sectioned at $4 \mu \mathrm{m}$; (iv) stained with Haematoxylin Eosin (H.E.) and finally (v) observed by optical microscopy (Eclipse 50i - Nikon instrument).

\section{Results}

The results of the statistical descriptive analysis based on central tendency and concentration indexes of the $\mathrm{Cd}$ concentration are shown in Table 1 and Figure 1. In the group of forty animals raised in the Campania region, the limits imposed by EC Reg. 1881/2006 and EC Reg. 488/2014 (1 $\mathrm{mg} / \mathrm{kg}$ for the kidney, $0.50 \mathrm{mg} / \mathrm{kg}$ for the liver and $0.050 \mathrm{mg} / \mathrm{kg}$ for muscle) were exceeded in three renal samples, which showed values of $1.53,1.22$ and $1.1 \mathrm{mg} / \mathrm{kg}$ respectively; in three hepatic samples, which presented values of $0.72,0.64$ and
$0.61 \mathrm{mg} / \mathrm{kg}$, and in five muscle samples, with values of $0.16,0.16,0.09,0.08$ and 0.07 , respectively. On the other hand, in the group of animals raised and slaughtered in the province of Bari, the level of $\mathrm{Cd}$ contamination was much lower. Indeed, none of the 26 samples examined exceeded the limits imposed by the European Regulations.

The strongest relationship in $\mathrm{Cd}$ concentrations occurred between liver and kidney tissue $(r=0,8318$ in the samples of the Campania region and $r=0,8421$ in the samples of the Apulia region), even if this relationship was present also between liver tis- sue and muscle $(r=0,5516$ in the samples of the Campania region and $r=0,7218$ in the samples of the Apulia region, respectively) and between kidney tissue and muscle $(r=0,5458$ in the samples of the Campania region and $r=0,6142$ in the samples of the Apulia region, respectively) (Table 2).

The histological analysis showed typical, but not pathognomonic lesions in the renal samples from the animals raised in the provinces of Naples and Caserta. Moreover, these lesions were visible only in the samples with a concentration of the metal of $1.53,1.22$ and $1.1 \mathrm{mg} / \mathrm{kg}$. These samples

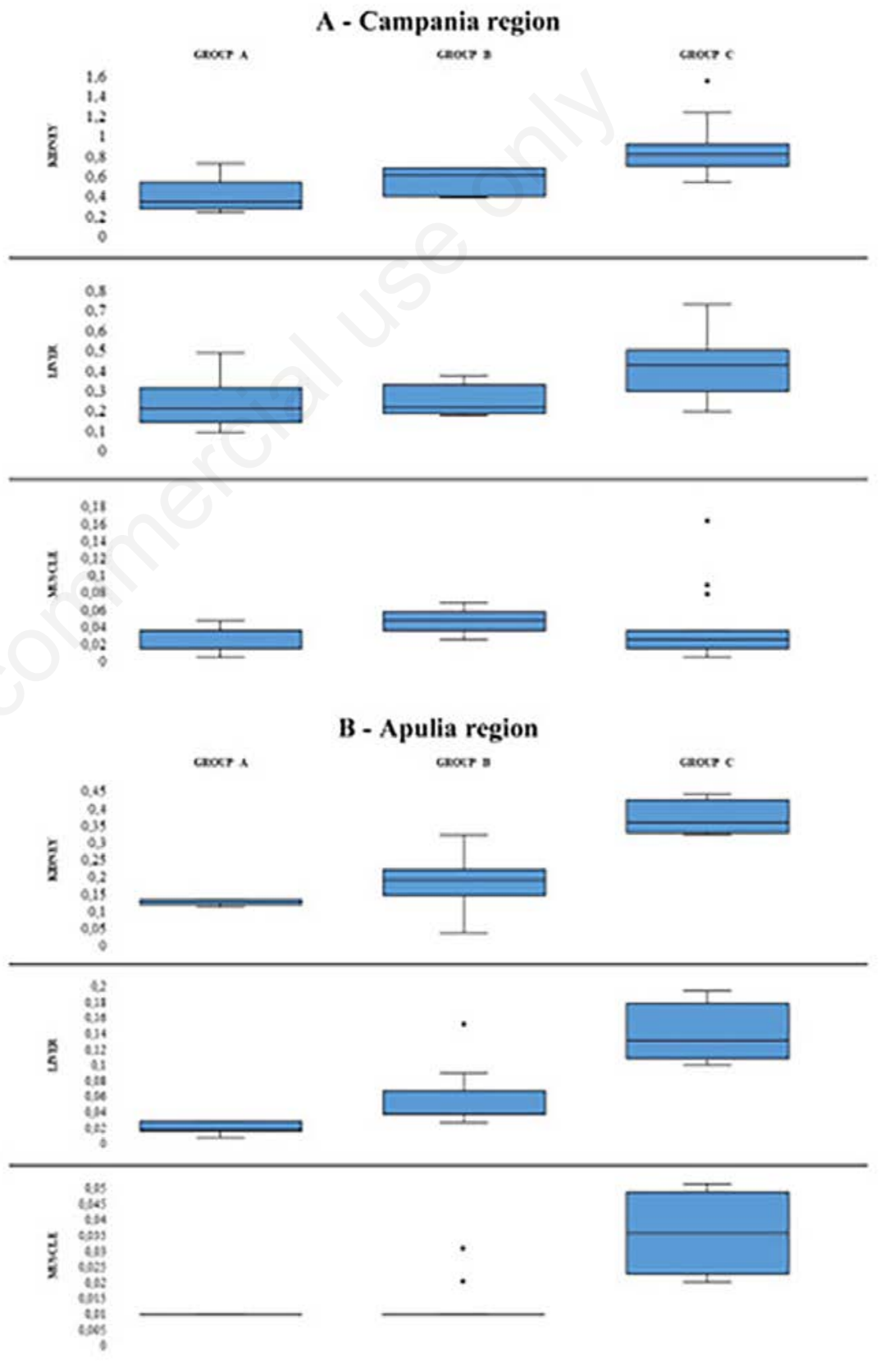

Figure 1. Distribution of Cd concentrations. 
Table 1. Descriptive statistics.

\begin{tabular}{|c|c|c|c|c|c|c|c|c|c|}
\hline & $\begin{array}{c}\text { Group A } \\
\text { (N 15) }\end{array}$ & $\begin{array}{c}\text { Group B } \\
\text { (N 5) } \\
\text { Kidney }\end{array}$ & $\begin{array}{c}\text { Group C } \\
(\mathrm{N} 20)\end{array}$ & $\begin{array}{c}\text { Group A } \\
\text { (N 15) }\end{array}$ & $\begin{array}{c}\text { Group B } \\
\text { (N 5) } \\
\text { Liver }\end{array}$ & $\begin{array}{c}\text { Group C } \\
(\mathrm{N} 20)\end{array}$ & $\begin{array}{c}\text { Group A } \\
\text { (N 15) }\end{array}$ & $\begin{array}{c}\text { Group B } \\
\text { (N 5) } \\
\text { Muscle }\end{array}$ & $\begin{array}{c}\text { Group C } \\
(\mathrm{N} 20)\end{array}$ \\
\hline \multicolumn{10}{|c|}{ Campania region } \\
\hline Average & 0,4013 & 0,556 & 0,846 & 0,2393 & 0,252 & 0,412 & 0,0307 & 0,05 & 0,046 \\
\hline Median & 0,35 & 0,61 & 0,81 & 0,22 & 0,22 & 0,425 & 0,04 & 0,05 & 0,03 \\
\hline SE & 0,0367 & 0,0630 & 0,0510 & 0,0284 & 0,0348 & 0,0334 & 0,0037 & 0,0063 & 0,0099 \\
\hline SD & 0,1420 & 0,1408 & 0,2283 & 0,1099 & 0,0779 & 0,1492 & 0,0144 & 0,0141 & 0,0441 \\
\hline Kurtosis & 0,3731 & $-3,1429$ & 3,3449 & 0,5745 & $-0,1564$ & $-0,5246$ & $-1,4252$ & 2,0000 & 3,1717 \\
\hline Skewness & 1,0345 & $-0,4384$ & 1,6023 & 0,9579 & 1,0143 & 0,2483 & $-0,2994$ & 0,0000 & 1,9556 \\
\hline Minimum & 0,25 & 0,4 & 0,54 & 0,1 & 0,18 & 0,2 & 0,01 & 0,03 & 0,01 \\
\hline Maximum & 0,73 & 0,68 & 1,53 & 0,49 & 0,37 & 0,72 & 0,05 & 0,07 & 0,16 \\
\hline \multicolumn{10}{|c|}{ Apulia region } \\
\hline Average & 0,135 & 0,18625 & 0,365 & 0,0217 & 0,0544 & 0,1375 & 0,01 & 0,013125 & 0,035 \\
\hline Median & 0,14 & 0,195 & 0,355 & 0,02 & 0,04 & 0,13 & 0,01 & 0,01 & 0,035 \\
\hline SE & 0,0034 & 0,0159 & 0,0240 & 0,0031 & 0,0076 & 0,0189 & 0,0000 & 0,0018 & 0,0065 \\
\hline SD & 0,0084 & 0,0634 & 0,0480 & 0,0075 & 0,0305 & 0,0377 & 0,0000 & 0,0070 & 0,0129 \\
\hline Kurtosis & 1,4286 & 0,9866 & 0,5784 & $-0,1038$ & 6,2121 & 2,2271 & I & 3,0046 & $-1,2000$ \\
\hline Skewness & $-1,5367$ & $-0,1712$ & 1,0154 & $-0,3126$ & 2,3155 & 1,1293 & I & 2,0816 & 0,0000 \\
\hline Minimum & 0,12 & 0,05 & 0,32 & 0,01 & 0,03 & 0,1 & 0,01 & 0,01 & 0,02 \\
\hline Maximum & 0,14 & 0,32 & 0,43 & 0,03 & 0,15 & 0,19 & 0,01 & 0,03 & 0,05 \\
\hline
\end{tabular}

SE: standard error; SD: standard deviation.

showed extended histological alterations of the whole renal morpho-functional unit; in fact, a very compromised kidney picture was observed: (i) the proximal convoluted tubules appeared dilated, filled with protein-like amorphous substance and with localized necrotic areas and (ii) the renal glomerulus showed an alteration of epithelial cells and the capillaries were clearly visible (Figure 2). On the other hand, in the renal samples in which the concentration of $\mathrm{Cd}$ was between 0.75 and $0.95 \mathrm{mg} / \mathrm{kg}$, the alterations were found only in the proximal convoluted tubules. Histological examination conducted on the hepatic parenchyma, showed only different degrees of steatosis, both in the samples from the animals raised in the province of Bari, and in the group of animals raised in the provinces of Naples and Caserta.

\section{Discussion}

Cadmium was present in all examined samples, both in the offal and in the muscular tissue, but the most alarming values were showed in the animals raised in the Campania region, in the provinces of Naples and Caserta. Indeed, only in the kidneys, livers and muscles of the animals from Campania region were found $\mathrm{Cd}$ levels exceeded the European limits for human

Table 2. Correlations ( $r$ Pearson) of metal concentrations in various tissues.

\begin{tabular}{lcc} 
Correlation & Campania region & Apulia region \\
Kidneys vs Liver & 0,8318 & 0,8421 \\
Kidneys vs Muscle & 0,5458 & 0,6142 \\
\hline Liver vs Muscle & 0,5516 & 0,7218 \\
\hline
\end{tabular}

consumption. The eleven samples examined that exceeded the limits imposed by the European Regulation concerned only six animals: (i) two presented the exceeding of the limits only in the liver and muscle respectively; (ii) three showed the exceeding of the limits in two organs simultaneously (two both in the kidney and in the muscle and one both in the liver and in the muscle); (iii) finally, one animal presented the exceeding of the limits in all three samples.

Moreover, in agreement with other studies (Al-naemi HS, 2011; Binkowski et al., 2016), the Cd concentration depended on the animal age, showing lower concentration in the younger buffaloes $(<6$ months) than in the older ones (groups B and $\mathrm{C}$ ). This correlation was confirmed by the classes of homogeneity constructed that, although different in number, were optimal since the dispersion around the average was low within the groups (Table 1). On the other hand, no differences were observed depending on the sex of the animals, which was in accordance with further studies (Paßlack at al., 2014).

Among the relationships studied, the strongest occurred in $\mathrm{Cd}$ concentrations between liver tissue and kidney tissue $(r=$ 0,8318 in the samples of the Campania region and $r=0,8421$ in the samples of the Apulia region) (Table 2). This relationship was generally known and was described in many species (Binkowski et al., 2016; Binkowski and Sawicka-Kapusta, 2015a; Nordberg et al., 2007). In fact, the liver and kidneys are especially prone to xenobiotic induced injury due to their central role in xenobiotic metabolism (Massanyi et al., 2014).

Conversely, the histological picture resulted independent of the animal age; in fact, it was observed both in subjects who have reached slaughter in the first months of their life (group A), and in those at the end of their careers (groups B and C). 


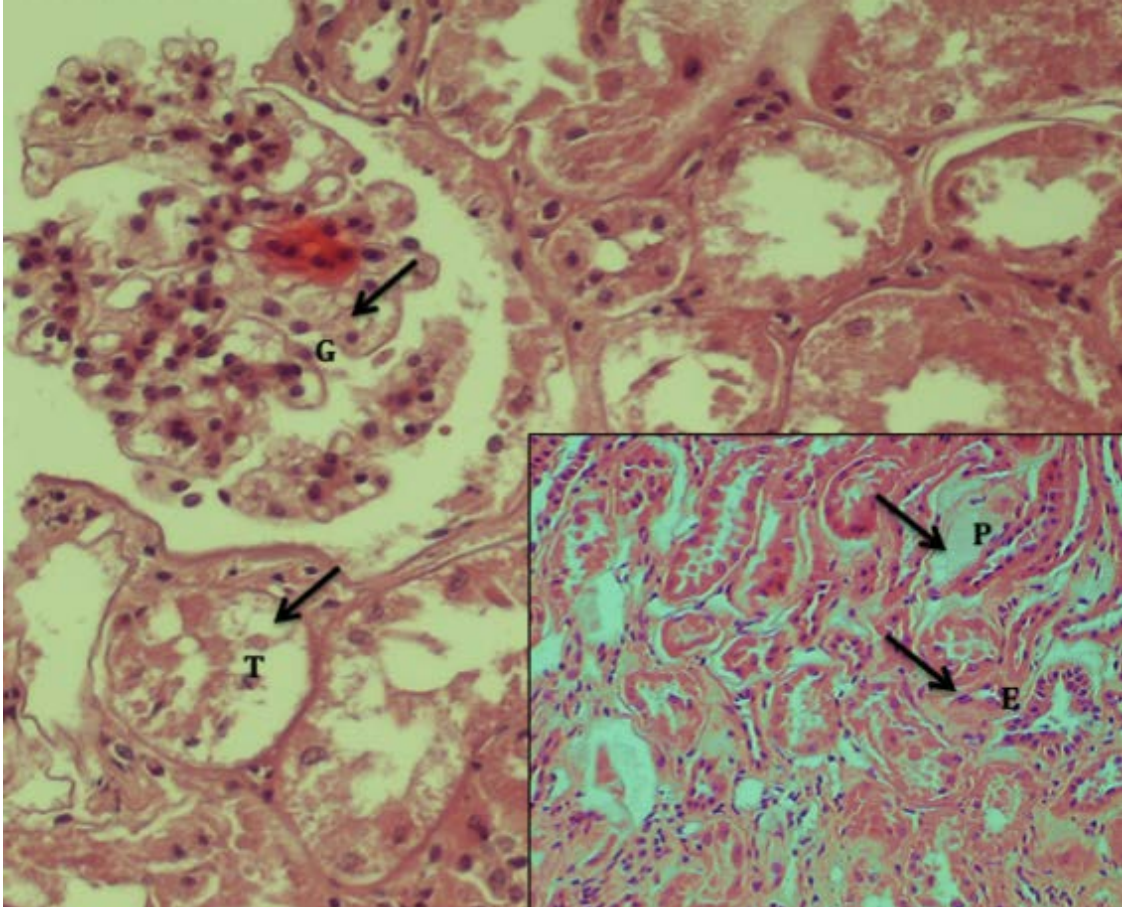

Figure 2. Kidney. (i) H.E. (Haematoxylin Eosin) 40x: alteration of epithelial cells and glomerular capillaries (G); dilatation and necrotic areas of proximal convoluted tubules (T). (ii) H.E. 20x: protein material (P); small areas of oedema (E).

\section{Conclusions}

The buffaloes of our investigation were all suitable for slaughter following the antemortem visit and therefore suitable for human consumption following the postmortem inspection. The most worrying data emerged after the survey conducted on the samples from Campania region was the exceeding of the limits allowed in the muscle $(0.05 \mathrm{mg} / \mathrm{kg})$.

As demonstrated in recent studies (Oladipo et al., 2016; Dumkova et al., 2016), histological lesions had a diagnostic role only in the renal samples in which $\mathrm{Cd}$ concentrations were higher than 0.75 $\mathrm{mg} / \mathrm{kg}$. Therefore, at concentrations of $\mathrm{Cd}$ ranging from 0.75 to $0.95 \mathrm{mg} / \mathrm{kg}$, the lesions were limited to proximal contorted tubules; while the lesions involved the whole morpho-functional unit of the kidney as the metal concentration increased.

The levels of $\mathrm{Cd}$ contamination found in the samples examined suggest that it would be correct to exclude from the human consumption, as it happens for the equines, the kidney and the liver, especially from the animals raised in some geographical areas with a high rate of pollution. This may be possible by mapping the risk areas and by a continuous and constructive collaboration since the quality of the animal products destined for human consumption is affected by several factors acting throughout the production chain. Whereas a recent study (Bozzo et al., 2018) reported that the perception of animal welfare has increased among European consumers, the welfare of livestock must be preserved and a good environment is a fundamental pre-requisite to improve livestock production quality.

The present data underline the relevance of buffalo organs in the food chain for human $\mathrm{Cd}$ exposure and confirm the scientific opinion of the EFSA Panel on Contaminants in the Food Chain (CONTAM 2009; 2011), according to which the human $\mathrm{Cd}$ exposure should be reduced. Therefore, it is important to keep studying the cadmium levels tolerated by human and denounce what might be underestimated chemical hazards in meat. Considering that the buffalo breeding is in continuous growth thanks to the dietetic-nutritional and organoleptic characteristics of its meat, it should be considered the possibility of inserting this animal species in the community Regulations (EC Reg. 1881/2006; EC Reg. 488/2014) as a separate species and not in common with the bovine one.

\section{References}

Al-naemi HS, 2011. Estimation of lead and cadmium levels in muscles, livers and kidneys of slaughtered cattle in Mosul city. Vet. Public Hlth. Dept., College of Vet. Med., Mosul Univ., Iraq. Vol. 39 n. 3.

Antoniou V, Tsoukali-Papadopoulou H, Epivatianos P, Nathanael B, 1989. Cadmium concentrations in beef consumable tissues in relation to age of animals and area of their breeding. Bull Environ Contam and Toxicol 43:915919.

Binkowski ŁJ, Merta D, Przystupinska A, Sołtysiak Z, Pacon J, Stawarz R, 2016. Levels of metals in kidney, liver and muscle tissue and their relation to the occurrence of parasites in the red fox in the Lower Silesian Forest in Europe. Chemosphere 149:161-167.

Binkowski ŁJ, Sawicka-Kapusta K, 2015a. Cadmium concentrations and their implications in Mallard and Coot from fish pond areas. Chemosphere 119:620625.

Bozzetta E, Pezzolato M, Maurella C, Varrello K, Richelmi GB, Draisci R, Ferranti C, D'Angelo A, Caramelli M, 2011. Development of an enhanced histopathological approach to detect low-dose dexamethasone illicit treat- 
ment in veal calves. Food Addit Contam 28:9, pp. 1187-1192.

Bozzo G, Bonerba E, Ceci E, Colao V, Tantillo G, 2011. Determination of ochratoxin A in eggs and target tissues of experimentally drugged hens using HPLC-FLD. Food Chem 126:2781282.

Bozzo G, Barrasso R, Marchetti P, Roma R, Samoilis G, Tantillo G, Ceci E, 2018. Analysis of stress indicators for evaluation of animal welfare and meat quality in traditional and Jewish slaughtering. Animals 8:43.

Demirel S, Tuzen M, Saracoglu S, Soylak M, 2008. Evaluation of various digestion procedures for trace element contents of some food materials. J. Hazard. Mater 152:1020-1026.

Dumkova J, Vrlikova L, Vecera Z, Putnova B, Docekal B, Mikuska P, Fictum P, Hampl A, Buchtova M, 2016. Inhaled Cadmium Oxide Nanoparticles: Their in Vivo Fate and Effect on Target Organs. Int J Mol Sci 17(6):874.

European Commission, 2006. Regulation of the European Parliament and of the Council of 19 December 2006 setting maximum levels for certain contaminants in foodstuffs, 1881/2006/EC. In: Official Journal, L 364/5, 20/12/2006.

European Commission, 2014. Regulation of the European Parliament and of the Council of 12 May 2014 amending Regulation (EC) No 1881/2006 as regards maximum levels of cadmium in foodstuffs, 488/2014/EU. In: Official Journal, L 138/75, 13/5/2014.

European Food Safety Authority, 2012. Cadmium dietary exposure in the European population. The EFSA Journal 10(1):2551.

European Food Safety Authority, 2009. Scientific Opinion of the Panel on Contaminants in the Food Chain (Question No EFSA-Q-2007-138). Adopted on 30 January 2009. The EFSA Journal 980:1-139.

FAO/WHO (Food and Agriculture Organization/World Health Organization), 1993. Evaluation of certain food additives and contaminants (Forty-first report of the Joint FAO/WHO Expert Committee on Food Additives). WHO Technical Report Series, No. 837. [TRS 837-JECFA 41].
Giofrè F, Saladino A, Caparello G, Marino D, Naccari F, 2000. Livelli di cadmio in campioni di muscolo e fegato di cavalli allevati nella regione Calabria. Large Anim Rev 6(2):5-9.

Groten JP, Van Bladeren PJ, 1994. Cadmium bioavailability and health risk in food. Trends Food Sci Technol 5:5055.

IARC, 1972. Monographs on the Evaluation of the Carcinogenic Risk of Chemicals to Humans. Geneva: World Health Organization, International Agency for Research on Cancer. Available at: http://monographs. iarc.fr/ENG/Classification/index.php.

Italian Ministry of Health, 2003. Attuazione della direttiva n. 2003/40/CE della Commissione nella parte relativa ai criteri di valutazione delle caratteristiche delle acque minerali naturali di cui al decreto ministeriale 12 novembre 1992 , n. 542, e successive modificazioni, nonché alle condizioni di utilizzazione dei trattamenti delle acque minerali naturali e delle acque di sorgente, Ministerial Decree 29/12/2003.

Italian Ministry of Health, 2009. Direzione generale della sicurezza degli alimenti e della nutrizione. National Residual Plan, 2009. Available at: http://www.salute.gov.it/imgs/C_17 pubblicazioni_1296_allegato.pdf.

Lara PCP, Fabrino HJF, Germano A, \& Da Silva JBB, 2012. Development and validation of a method for $\mathrm{Cd}, \mathrm{Pb}$ and $\mathrm{As}$ analysis in bovine, equine and poultry liver by inductively coupled plasma mass spectrometry. Food Additives \& Contaminants: Part A 29:4, 609-616.

Mantovani P, Piccinini S, 2002. Le fonti di apporto di metalli pesanti ai terreni. L'informatore agrario vol. 20, pp 29-33.

Massanyi P, Stawarz R, Halo M, Formicki G, Lukac N, Cupka P, Schwarcz P, Kovacik A, Tusimova E, Kovacik J, 2014. Blood concentration of copper, cadmium, zinc and lead in horses and its relation to haematological and biochemical parameters. J Environ Sci Health, Part A 49:973-979.

Mehmood A, Sarfraz RA, Qudoos A, Akbar F, 2014. Appraisal of Some Heavy Metals in Organ Meat from NonIndustrialized Areas of Faisalabad, Pakistan. Global Vet 12 (1):98-103.
Mitsumori K, Shibutani M, Sato S, Onodera H, Nakagawa J, Hayashi Y, Ando M, 1998. Relationship between the development of hepato-renal toxicity and cadmium accumulation in rats given minimum to large amounts of cadmium chloride in the long term: preliminary study. Arch Toxicol 72:545-552.

Nagajyothi PC, Dinakar N, Prasad TNVKV, Suresh C, Damodharam T, 2008. Heavy metal toxicity: Industrial effluent on groundnut (Arachis hypogaea L.) seedlings. J. Appl. Sci. Res. 4:110-121.

Nordberg GF, Fowler BA, Nordberg M, Friberg LT, 2007. Handbook on the Toxicology of Metals. Elsevier, London.

Nordberg GF, Jin T, Nordberg M, 1994. Subcellular targets of cadmium nephrotoxicity: cadmium binding to renal membrane proteins in animals with or without protective metallothionein synthesis. Environ. Health Perspect 102 Suppl. 3:191-194.

Oladipo OO, Ayo JO, Ambali SF, Bisalla M, 2016. Evaluation of hepato-renal impairments in Wistar rats co-exposed to low-dose lead, cadmium and manganese: insights into oxidative stress mechanism. Toxicol Mech Methods 15:1-32.

Paßlack N, Mainzer B, LahrssenWiederholt M, Schafft H, Palavinskas R, Breithaupt A, Neumann K, Zentek J, 2014. Concentrations of strontium, barium, cadmium, copper, zinc, manganese, chromium, antimony, selenium and lead in the equine liver and kidneys. SpringerPlus 3:343.

Plumlee KH, Johnson B, Gardner IA, 1996. Heavy metal concentrations in injured Racehorses. Vet Hum Toxicol 38(3):204-206.

Pozzali U, Rattizzi C, Tessore F, 1995. Residui involontari nelle carni di equino: il cadmio. Il Progresso Veterinario 2:53-55.

Roychoudhury S, Massanyi P, Bulla J, Choudhury MD, Lukac N, Filipejova T, Trandzik J, Toman R, Almasiova V, 2010. Cadmium toxicity at low concentration on rabbit spermatozoa motility, morphology and membrane integrity in vitro. J. Environ. Sci. Health. Part A 45:1374-1383. 